\title{
Patrón de citoquinas en niños con dengue hemorrágico en Neiva, Colombia
}

\author{
Fecha de recibido: 11 de abril de 2010 • Fecha de aprobación: 30 de mayo de 2010
}

\begin{abstract}
Cytokines play a critical role in the pathogenesis of dengue hemorrhagic fever and have been used as markers of severity disease. In this study we measured serum levels of five cytokines in dengue infected children and correlate their levels with shock and complicated forms such as myocarditis, hepatitis or bleeding.
\end{abstract}

Methods: 30 patients who met WHO criteria for dengue hemorrhagic fever (DHF) were enrolled and classified into two groups: group one without shock (grade I and II) and group two with shock (grade III and IV). Serum levels of TNF $\alpha$, IL-6, IL-10, IL-4 and IFN $\gamma$ were measured by ELISA at first day of defervescence and were compared with serum levels of 28 healthy children.

Results: from 30 patients, 9 were assigned to group number one (median age 67 months) and 21 to group two (median age 42 months). Statistical differences were found between dengue infected patients and controls: controls IL-6 (5.2 pg/ml), group $1(485 \mathrm{pg} / \mathrm{ml})(\mathrm{p}=0.002)$ and group $2(190 \mathrm{pg} / \mathrm{ml})(\mathrm{p}=0.001) ; \mathrm{TNF} \alpha$, control group $(70 \mathrm{pg} / \mathrm{ml})$, group $1(586.7 \mathrm{pg} / \mathrm{ml})(\mathrm{p}=0.021)$ and group $2(320.7 \mathrm{pg} / \mathrm{ml})(\mathrm{p}<0.001)$ and for IFN $\gamma$, control group $(12.3 \mathrm{pg} / \mathrm{ml})$, group $2(27.5 \mathrm{pg} / \mathrm{ml})(\mathrm{p}=0.019)$. However, we could not find correlation between cytokines and shock or complicated forms of illness. IL-4 and IL-10 did not show differences between any tested groups.

Conclusion: IL-6, TNF $\alpha$ and IFN $\gamma$ are elevated in children with dengue hemorrhagic fever, but there was not correlation with severe forms of shock.

Key words: Dengue, Dengue hemorrhagic fever (DHF), shock dengue syndrome (SDS), Cytokines.

Resumen. Las citoquinas juegan un papel crítico en la patogénesis de la fiebre dengue hemorrágico (FDH) y han sido usadas como marcadores de severidad. En este estudio se midieron los niveles de cinco citoquinas en niños infectados con dengue y se correlacionaron con el choque y las formas complicadas tales como miocarditis, hepatitis o sangrado.

Método: 30 pacientes que cumplían los criterios de la OMS para FDH fueron incluidos y clasificados en dos

* Grupo de Parasitología y Medicina Tropical, Programa de Medicina, Facultad de Salud, Universidad Surcolombiana, Neiva, Colombia.

*¥ Corresponding author: jrodriguez@usco.edu.co 
grupos: grupo 1, sin choque (grado I y II) y grupo 2, con choque (grado III y IV). Niveles séricos de TNF $\alpha$, IL-6, IL-10. IL-4 e IFN $\gamma$ fueron medidos por ELISA en el primer día de la defervescencia y comparados con los respectivos niveles de 28 niños sanos.

Resultados: de los 30 pacientes, 9 fueron clasificados en el grupo número 1 (media de edad de 67 meses) y 21 en el grupo 2 (media de la edad 42 meses). Diferencias estadísticamente significativas fueron encontradas entre niños infectados con dengue y controles sanos: sanos IL-6 (5,2 pg/ml), grupo $1(485 \mathrm{pg} / \mathrm{ml})(\mathrm{p}=0,002)$ y grupo $2(190 \mathrm{pg} / \mathrm{ml})(\mathrm{p}=0,001)$; TNF $\alpha$, grupo control $(70 \mathrm{pg} / \mathrm{ml})$, grupo $1(586,7 \mathrm{pg} / \mathrm{ml})(\mathrm{p}=0,021)$ y grupo 2 $(320,7 \mathrm{pg} / \mathrm{ml})(\mathrm{p}<0,001)$ y para IFN $\gamma$, grupo control $(12,3 \mathrm{pg} / \mathrm{ml})$, grupo $2(27,5 \mathrm{pg} / \mathrm{ml})(\mathrm{p}=0,019)$. Sin embargo, no se encontró correlación entre las citoquinas y el choque o las otras formas evaluadas. IL-4 e IL-10 no fueron diferentes en ninguno de los grupos analizados.

Conclusión: IL-6, TNF $\alpha$ e IFN $\gamma$ están elevadas en niños con $\mathrm{FDH}$, pero no hubo correlación con las formas severas de choque.

Palabras clave: dengue, fiebre dengue hemorrágico $(\mathrm{DH})$, síndrome de choque por dengue (SSD), citoquinas.

\section{INTRODUCTION}

Dengue hemorrhagic fever (DHF) has emerged as the most important arbovirus disease in man in the last three decades. It has been estimated that about 50 million cases of DF occur every year with about 250,000 to 500,000 cases of $\mathrm{DHF}(1)$. In 2001 there was an unprecedented global dengue epidemic activity in American countries, the Pacific islands and Asia. During 2002, more than 30 Latin American countries reported over 10,000,000 DF cases with large number of DHF cases(2). In Colombia global incidence rate is about 13 cases for 100,000 habitants but in some regions such as Santander or Huila this rate is higher than 60 cases for 100,000 and has become a leading cause of hospitalization and death among children(3).

Dengue virus (DV) infection has a spectral presentation from asymptomatic forms to dengue fever (DF) and dengue hemorrhagic fever (DHF) with life threatening situations of shock, bleeding or more recently described complicated atypical forms like hepatitis, encephalitis, myocarditis(4-6).

Studies have shown the cytokines as a pivotal piece in the pathogenesis of dengue hemorrhagic fever that reflects an imbalance between $T$ helper 1 (Th1) and Th2 response. Thus, an early Th1 response has been characterized with a production of IFN $\gamma$ and IL-2 which mediate cellular activation needed for viral clearance and later a Th2 response with IL-4, IL-5, IL-6, IL-10 and IL-13 release which are responsible for pro inflammatory effect with endothelium and homeostatic alterations leading to shock and bleeding forms(7). Recently, others cytokines such as IL8(8), IL-1Ra(9), IL-12(10), hCTF(7), MIF(11) has been obtained from another cells such as endothelium, neutrophil, dendritic cells and hepatocytes when these are infected by dengue virus, which gives us an idea of complexity of cytokine role in dengue hemorrhagic fever. However, exist a variation of cytokines pattern according to dengue virus serotype and HLA polymorphism(12) that could explain individual patterns of cytokine in each population and why some regions have more tendency to dengue hemorrhagic fever with severe and complicated forms. In this study we will determine cytokines profile in a population of children from Neiva, Colombia and to correlate with severity of disease.

\section{MATERIALS AND METHODS}

\section{Patient enrollment}

This study included thirty patients under 13 years old who were admitted to Pediatric Department of Hospital Universitario de Neiva between june 2004 to June 2005. Entry criteria were clinical diagnosis of DHF using WHO criteria before the results of serological studies were known and severity of illness was graded according to the presence of shock into two groups: group one without shock and group two with shock. 28 healthy children in the out patient department served as a control group. Epidemiological and clinical dates were recorded at time of day sixth when measure of cytokines were made.

The study was approved by the Medical ethics Committee of Medicine program from Universidad Surcolombiana and by the ethics committee of the Hospital Universitario de Neiva. Informed consent was obtained from the parent of each patient included in the study.

\section{Laboratory testing}

Blood sample was obtained at first day of defervescence ( +2 day of disease). Cytokines $\mathrm{TNF} \alpha, \mathrm{IL}-6, \mathrm{IL}-10, \mathrm{IL}-4$ and IFN $\gamma$ were measured 
with an ELISA technique (Anogen, Ontario, CA) according to the manufacturer's instructions. These cytokines were measured also in healthy patients as control. The limit detection of every cytokine was: IL-4 $(4.3 \mathrm{pg} / \mathrm{mL})$, IL-6 $(1.7 \mathrm{pg} / \mathrm{mL})$, IL-10 $(2 \mathrm{pg} / \mathrm{mL}), \mathrm{TNF} \alpha(4 \mathrm{pg} / \mathrm{mL})$ and IFN $\gamma$ $(7.5 \mathrm{pg} / \mathrm{mL})$. Standards were included in each assay and the curve was used for estimation of cytokine concentration (in $\mathrm{pg} / \mathrm{mL}$ ) by regression analysis. Ig $\mathrm{M}$ for dengue virus was made using ELISA technique as well (PanBio).

Coagulation test (prothrombine time, partial thromboplastine time and platelets count), liver function test (alanine aminotransferase-ALT, aspartate aminotransferase-AST) and electrocardiograph were made to determine liver, haemostatic and myocardium involvement respectively.

\section{Date analysis}

All data are presented as median and range. Differences in levels of IL-6, TNF $\alpha$, IL-10, IFN $\gamma$ and IL-4 between cases and controls as well as between controls, shock and no shock patients were analyzed by the Kruskal-Wallis follow by Dunn's multiple comparison test. P value of less than 0.05 was considered to represent a significant difference. All statistical calculations were done using SPSS 6.0 and Graphpad prism 4.0 software.

\section{RESULTS}

From a total of thirty patients, nine $(30 \%)$ were classified in the group without shock and twenty one $(70 \%)$ in the group with shock from whom, five patients had profound shock with narrow of pulse pressure lesser than $20 \mathrm{mmHg}$.

The median age, gender distribution and signs and symptoms in each group are presented in Table 1. Forty three percent of patients included were younger than 4 years old with a youngest has 6 months and older has 12 years. We observed that patients in the group with shock were younger (median age 48 months) and showed more symptoms compared to group without shock (median age 74 months).

Patients has a median of fever 4.6 days because we are reference hospital. Between clinical signs hepatomegaly was a constant finding followed by pleural effusion (median 30\%) and bleeding in a $60 \%$ of patients in both groups.

Between laboratory test, platelets count were under $50,000 \times \mathrm{mm}^{3}$ in around $50 \%$ of patients and less

Table 1. Clinical characteristics.

\begin{tabular}{|c|c|c|}
\hline Characteristics & $\begin{array}{c}\text { Group } 1 \\
\mathbf{N}=9\end{array}$ & $\begin{array}{c}\text { Group } 2 \\
N=21\end{array}$ \\
\hline $\begin{array}{l}\text { Age median in months (range) } \\
\text { Gender Male/ Female } \\
\text { Fever days median (range) } \\
\text { Headache } \\
\text { Vomiting } \\
\text { Bleeding (\%) } \\
\text { Epistaxis } \\
\text { Gyngivorhragie } \\
\text { Melene } \\
\text { Systolic pressure median in } \mathrm{mm} \mathrm{Hg}(\mathrm{SD}) \\
\text { Hepatomegaly (cms) }\end{array}$ & $\begin{array}{c}74(6-128) \\
06-\mathrm{mar} \\
4,2(1-6) \\
23 \% \mathrm{n}=7 \\
23 \% \mathrm{n}=7 \\
15 \\
\mathrm{n}=3 \\
\mathrm{n}=1 \\
\mathrm{n}=1 \\
100(90-112) \\
2,4 \mathrm{~cm}\end{array}$ & $\begin{array}{c}48(7-120) \\
10-\mathrm{nov} \\
4,7(2-6) \\
43 \% \mathrm{n}=13 \\
50 \% \mathrm{n}=15 \\
26 \\
\mathrm{n}=5 \\
\mathrm{n}=1 \\
\mathrm{n}=3 \\
89(80-106) \\
3,1 \mathrm{~cm}\end{array}$ \\
\hline $\begin{array}{l}\text { Laboratory test } \\
\% \text { Hemoconcentration-median (range) } \\
\text { Platelet count x103 (ul/mm3) median (range) } \\
\text { AST U/1 median (range) } \\
\text { ALT U/1 median (range) } \\
\text { Prothrombine time (sec) median (range) } \\
\text { Partial thromboplastine time (sec) median (range) } \\
\% \text { Pleural Effusion index median (range) }\end{array}$ & $\begin{array}{c}8.4(4.5-11.9) \\
32.8(11.1-46) \\
227(45-456) \\
81(79-179) \\
15(12-18) \\
58(40-63) \\
10(7-15)\end{array}$ & $\begin{aligned} 24 & (11-34) \\
38.9 & (10-56.1) \\
175 & (89-546) \\
127 & (70-184) \\
20 & (11-118) \\
65 & (41-124) \\
30 & (16-39)\end{aligned}$ \\
\hline
\end{tabular}


of $20,000 \times \mathrm{mm}^{3}$ in $20 \%$ of patients; prothrombine time has a median of $20 \mathrm{sec}$ with a higher value of $118^{\prime \prime}$ and partial thromboplastine time has a mean value of $65^{\prime \prime}$ with a higher value of $124^{\prime \prime}$.

Aminotransferase levels were higher for AST with a median value of $403.1 \mathrm{U} / 1$ in both groups (227 U/1 group 1 and $175 \mathrm{U} / 1$ group 2) compared to ALT levels of $171.5 \mathrm{U} / 1$ (81 u/1 group 1 and $127 \mathrm{U} / 1$ group 2) with AST/ALT ratio of 2.3 as were described for hepatitis dengue.

Electrocardiograph was abnormal in 8 patients with rhythm alteration and ST changes however echocardiogram was not available in these patients.

Despite clinical and laboratory test were more abnormal in patients with shock we did not find statistically differences between groups for any of this variables.
Based in clinical and laboratory findings were identified: $11(36.6 \%)$ cases of hepatitis, $8(26.6 \%)$ cases suggestive of myocarditis and 13 (43.3\%) cases of bleeding.

Pattern of cytokines in dengue infected children

Serum levels of TNF $\alpha$, IL-6, IFN $\gamma$, IL-10 and IL-4 in patients with dengue hemorrhagic fever in all groups are summarized in Figure 1. P of KruskalWallis test were $<0.01$ in all the cytokines analyzed. We found statistically differences for IL- 6 between controls and group one $(p=0.001)$ and group two $(\mathrm{p}=0.001)$; for $\mathrm{TNF} \alpha$ between controls and group one $(p=0.001)$ and group two $(\mathrm{p}<0.001)$ and IFN $\gamma$ between controls and shock patients $(p=0.019)$. Of note, serum levels of TNF $\alpha$ and IL- 6 were higher in patients without shock but there were not statistically difference between shock and no shock groups.
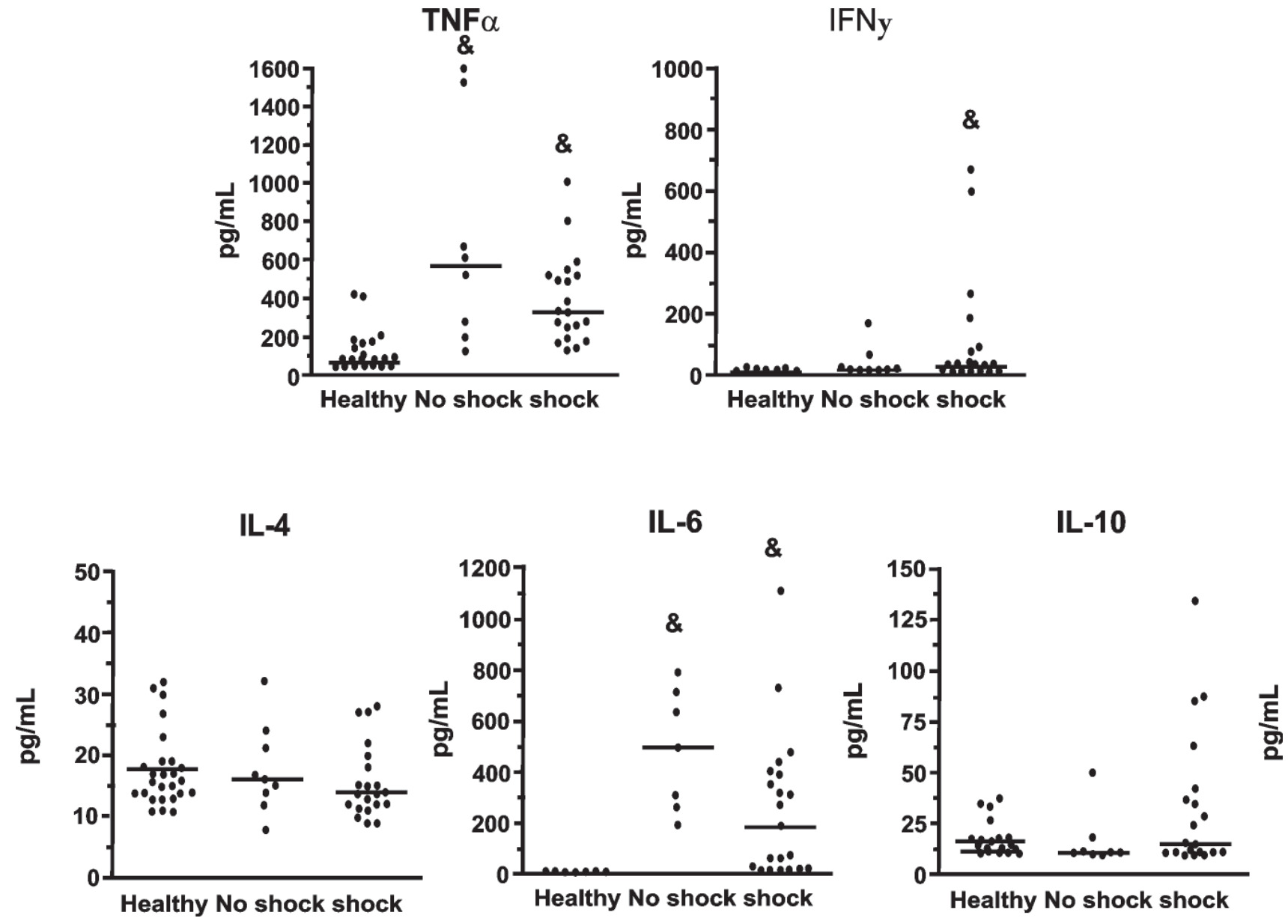

Figure 1. Pattern of serum levels of cytokines in healthy controls, dengue infected children without or with shock. Levels of cytokines were detected by ELISA six days after fever beginning. Lines represented the median. Kruskal-Wallis $P$ values are shown. 

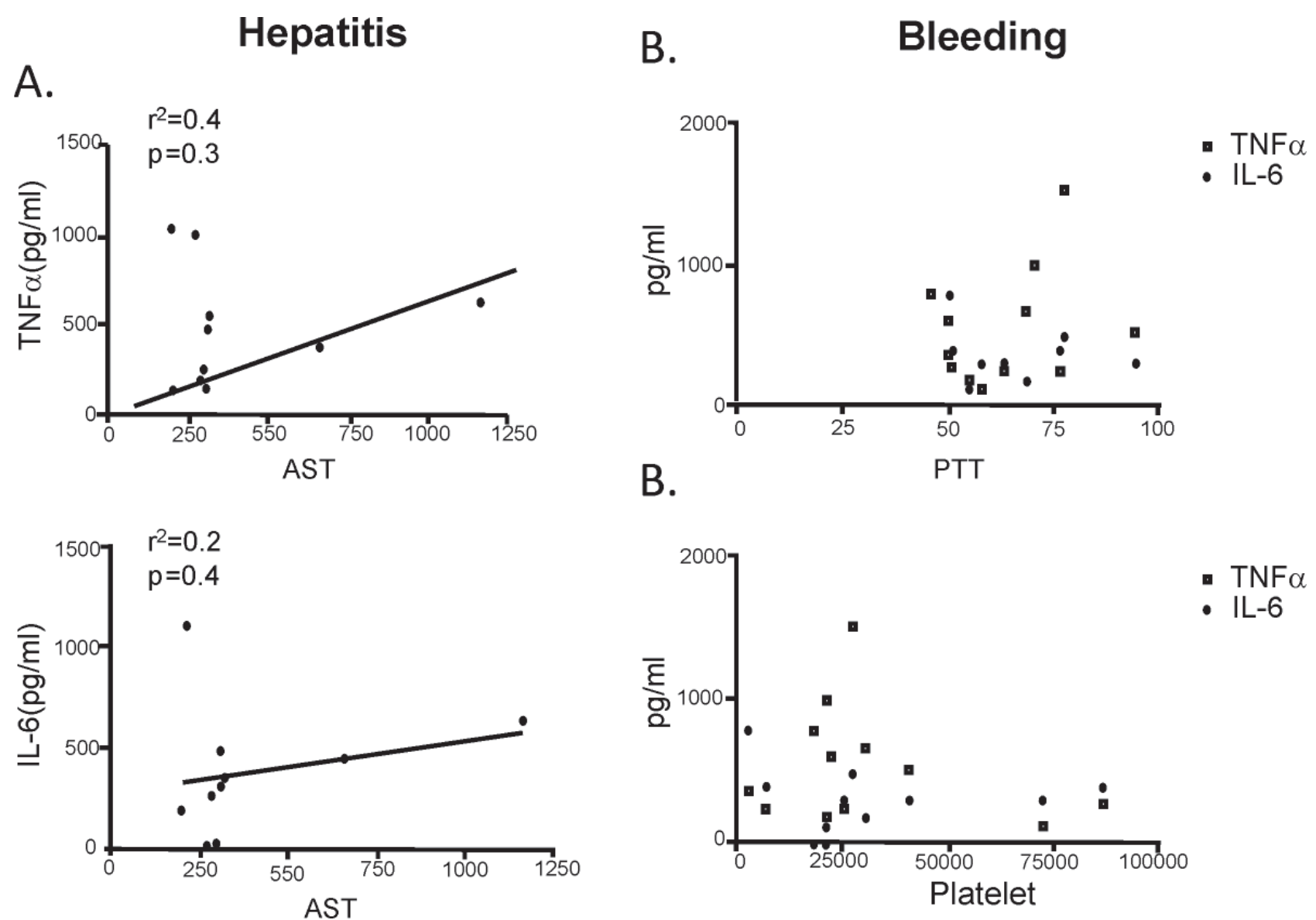

Figure 2. Hepatitis and bleeding are not related with TNF $\alpha$ or IL-6 levels. (A). No correlation was found between TNF $\alpha$ or IL-6 with AST (marker of hepatic injury) values (A) or bleeding sings (PTT and platelet number) (B).

IL-4 and IL-10 did not show statistical differences between healthy and dengue infected patients (Figure 1).

No correlation between levels of TNF $\alpha$ or IL-6 with a marker of Hepatic injury (AST) was found (Figure 2A). On the other hand, bleeding paraclinical signs (platelet number and PTT) were not clearly associated with and IL-6, TNF $\alpha$ and IL-10 levels as well.

Median days of stay was 6 and there were not deaths.

\section{DISCUSSION}

DF and DHF is an endemic-epidemic disease in Huila. Although there is a shift toward young adults(1) severe forms of DHF with shock continue to be more frequent in children as is showed in this study almost under five years old; symptoms such as vomiting, bleeding, abdominal pain are still alarm signs in dengue hemorrhagic fever because they are correlated with plasma leakage and shock.

In this study there was a higher incidence of hepatitis, myocarditis and bleeding in patients with shock thus, these complicated forms can be considered such a markers of severity. The liver involvement has been studied from asian epidemics where patients showed necrosis and hepatitis in focal and generalized forms with apoptotic changes similar to findings in yellow fever. There after, studies showed to hepatocytes and Kuppfer cells such as target of the virus and contribute to cytokines and mediators release such as IL-6, C-reactive protein and secretory phospholipase A2 (sPLA2) type II, which in turn may worse inflammatory response(13) Clinical studies have correlated severity with aminotransferase levels, an increase more than 10 folds normal value are considered such a marker of severity. It is consistent with our results that show high levels of aminotransferase specifically aspartate aminotransferase levels (AST, mean $403 \mathrm{U} / 1)$. 
Bleeding signs were present in $43 \%$ of patients with alteration in coagulation test. There are many explanations to haemostatic alterations in DHF /DSS such as a low production of coagulation factors due to liver involvement, imbalance between coagulation and fibrinolysis and an immune response against platelets and endothelium which are correlated to disease severity.

Myocarditis an unusual complication has been described as a mild bradycardia in late phase with few clinical signs and edema and hemorrhage in autopsies(14). However, in the last two years a severe form of myocarditis associated to dengue virus has been reported in our region with a fatality case of fulminant myocarditis $(15,16)$. In this study a $23 \%$ of patient had rhythm changes suggestive of myocarditis however it lacks of another test to confirm this diagnosis. To extent the analysis of the myocarditis, we recently show at the first time, the direct infection of human muscle cardiac cells by dengue virus in vivo(17).

It has been suggested that cytokines and chemical mediators play a role in the pathogenesis of DHF /DSS. One of the cells responsible of cytokine production is Tymphocyte that releases several cytokines including IFN $\gamma$, IL-2, IL-4, IL-5, IL-6, IL-10, and lymphotoxin. Monocytes/macrophages also produce TNF $\alpha$, IL-1, IL-1b, IL-6, and PAF(18), furthermore, some reports have demonstrated the production of cytokines or chemokines after in vitro DV infection of different types of cells, including endothelial cells $(19,20)$, blood monocytes(21), liver Kuppfer cells(22), mast cell/basophil line $(23,24)$ thus, cytokine responses is proportional to the infected cell mass(25).

The studies cytokines functions in dengue infection come from in vitro assays with specific cell bulk. In the clinical context it results difficult due to the complexity of cytokines network because they can activate cells synergistically or antagonistically and the net outcome will depend on the balance between various cytokine actions. It is clear that each cytokine pattern belong to a specific $\mathrm{T}$ helper response that will depend on antigen challenge. In dengue virus, studies show a Th1 pattern (IFN $\gamma$-IL2) in early phase of diseases and shift toward a Th2 response (IL4, IL5, IL6, IL10, IL13) in the late phase(26). From culture supernatants on infected cells, cytokines recovered on the first day post-infection were human cytotoxic factor (hCF), TNF $\alpha$, IL-2 and IL-6; their levels reached a peak on the second day, IFN $\gamma$ appeared on the 2 nd day with a peak on the 3rd day, IL 10, IL5 start later on the 4th day and IL-4 on the 6th day(27).

Nguyen et al. showed that infants with DHF/ DSS had levels of IFN $\gamma$ in the acute-phase significantly higher than those in samples from healthy control (56.2 vs. $4.1 \mathrm{pg} / \mathrm{ml}$ ) and were increased on day 4 to day 6 after the onset of fever and rapidly decreased on day 7 and during the convalescent phase, similar results were observed with TNF $\alpha$ levels which were elevated on day 4 to day 7 after the onset of fever and decreased on day 8 to day 19; IL-10 and IL-6 levels were also detected in the acute-phase but a lesser degree, thus is observed a Th1 predominant response in acute phase(25). Kurane et al., described T cell response in children with DHF/ DSS; they found IL-2 levels > $10 \mathrm{U} / \mathrm{ml}$ in $63 \%$ (26/41) of patients during days 3-8 after onset of fever and IFN $\gamma$ was detected in 97\% (34/35) of the patients with DHF on days 3-8 ( $p<0.001$ on days 3-6 and $p<0.02$ on days 7-8) Our results presented in fig 1 , shown a significant elevated levels of serum IFN $\gamma$ in shock group. This cytokine is specially produced by $\mathrm{T}$ cells and it will be consistent and indicate that $\mathrm{T}$ lymphocytes are activated in vivo during $\operatorname{DHF}^{(28)}$.

In our study, cytokines measured at sixth day showed important levels of IFN $\gamma$, TNF $\alpha$ and IL6 in DHF compared to controls but IL10 and IL4 levels were similar to healthy patients, which reflect a predominant and persistent Th1 response in our patients. We could not find correlation with severity and higher levels of TNF $\alpha$ and IL-6 were seen in patients without shock. In this regard, other studies have found similar results. Kurane in the study mentioned above, did not find significant differences in the levels of sIL-2R, sCD4, sCD8, IL-2, and IFN $\gamma$ among grades I, II, and III of DHF. Analysis in the Nguyen's study, do not found statistical differences in serum levels of IFN $\gamma$, TNF $\alpha$, IL-10, and IL- 6 between patients with no shock DHF and those with DSS, but a significantly higher elevation of IL-6 was observed in patients who died than in patients who survived the infection.

Despite of these clinical correlation were not conclusive, there are many studies which shown individual correlation of cytokine and severity. Elevated serum levels of TNF $\alpha$ and IL-6 as well as their association with severity of the disease and with DHF/DSS have been reported in human dengue infection(29). One fatal case in Rio 
de Janeiro, Brazil is described in one patient with serum level of $900 \mathrm{pg} / \mathrm{ml} \mathrm{TNF} \alpha(30)$. Experimental studies with anti TNF $\alpha$ based on the pre-terminal TNF $\alpha$ peak seen in lethal dengue model, found that animals treated with anti-TNF $\alpha$ serum have a better survive(31). Patients from the study showed very high serum levels of TNF $\alpha$ in dengue hemorrhagic patient compared to healthy patients. This finding can explain the high proportion of DHF vs DF seen in children from our region due to the important role of $\mathrm{TNF} \alpha$ in endothelium activation leading to plasma leakage and bleeding forms.

The IL-6 plays also a central role in pathogenesis of dengue due to its wide range of immune and hematopoietic activities and also its potential ability to induce the acute phase response, induction of terminal differentiation of B cells and activation of $\mathrm{T}$ cells. Different studies described IL-6 increased after dengue virus infection. Some studies show a correlation between severity of illness and IL-6 levels. One study in 186 children showed IL6 levels correlated with shock in DHF, they found higher plasma levels of IL- 6 in the shock group than in no shock group ( $p=0.05)$ however, although IL-6 levels were somewhat higher in the DHF patients than in the DF patients, this did not reach statistical significance. Another study in 24 patients with DHF (4 to 75 years old) showed levels of IL-6 significantly elevated in DHF/DSS patients but not in DF patients, compared to normal controls or patients with other febrile illness(32). In contrast with these studies, we found higher levels in DHF patients than controls but this cytokine was higher in the group without shock similar to a prospective study(25), in which IL-6 levels tended to be lower in patients in shock than those not in shock. This finding could be explaining by the cytokines kinetic where the highest levels of IL-6 are seen around 3 th day and decline thereafter. In this study patients were enrolled around sixth day when the clearance of this cytokine has begin.

IFN $\gamma$ could have a double function, one is the viral clearance thanks to $T$ cells and DC activation, and by the other hand could facilitate the antibody-depending enhancement (ADE) due to a up-regulate of the expression of FCy receptors. The increased number of dengue virus-infected monocytes/macrophages results in an elevation of T-cell activation, which results in the release of high levels of cytokines and chemical mediators with an increase in vascular permeability, plasma leakage, shock, and malfunction of the coagulation system $(18,33)$ which coincide with our finding of higher levels in the group with shock (Figure 1).

It has been show that IFN $\gamma$ was able to decrease the infection and virus titer in dendritic cells at $48 \mathrm{~h}(10)$. This is supported by clinical studies which show an elevation of IFN $\gamma$ in early phase on or before the day of defervescence, coinciding with disappearance of viraemia(34).

When serum levels of cytokines measured in children from the study are compared to other endemic regions for dengue we found a very high levels of TNF $\alpha$ and IL-6 (Figure 1). This fact can be explaining by an individual variation in HLA context $(25,35)$ that could be contributing to a more severity, shock and complicated forms seen in our patients. Consistent with that interpretation, a recent study in two ethnic colombian groups (afro-colombian and mestizos) show important and significant differences between the cytokine pattern present in patients with dengue fiver and $\mathrm{DHF}^{(36)}$.

However we could not demonstrated correlation between cytokines and shock, myocarditis, hepatitis and bleeding forms probably to be measured at specific point of time (sixth day) where the kinetic behavior of cytokines could not be seen.

In conclusion, at sixth day of disease our patients show a still a high proinflammatory and Th1 response which contribute to understanding of the disease and can support the hypothesis of benefit with immunomodulatory therapy in these patients.

\section{ACKNOWLEDGMENTS}

We would like to thank children enrolled in the study and the Medical and Paramedical personal of the Hospital Universitario de Neiva and Yamileth Monje for technical assistance. This study was supported by a grant from Vicerrectoría de Investigación, Universidad Surcolombiana, Neiva, Colombia.

\section{REFERENCES}

1. World Health Organization. Dengue guidelines for diagnosis, treatment, prevention and control: new edition. Geneva: World Health Organization; 2009. 
2. Chaturvedi UC, Shrivastava R, Nagar R. Dengue vaccines: problems and prospects. Indian J Med Res 2005;121(5):639-652.

3. Instituto Nacional de Salud. Análisis epidemiológico semana 35. Boletín Epidemiológico Instituto Nacional de Salud. 2006.

4. Nimmannitya S, Thisyakorn U, Hemsrichart V. Dengue haemorrhagic fever with unusual manifestations. Southeast Asian J Trop Med Public Health 1987;18(3):398-406.

5. Solomon T, Dung NM, Vaughn DW, Kneen R, Thao LT, Raengsakulrach B, et al. Neurological manifestations of dengue infection. Lancet 2000;355(9209):1053-1059.

6. Kamath SR, Ranjit S. Clinical features, complications and atypical manifestations of children with severe forms of dengue hemorrhagic fever in South India. Indian J Pediatr 2006;73(10):889-895.

7. Chaturvedi UC. The curse of dengue. Indian J Med Res 2006;124(5):467-470.

8. Bosch I, Xhaja K, Estevez L, Raines G, Melichar $\mathrm{H}$, Warke $\mathrm{RV}$, et al. Increased production of interleukin-8 in primary human monocytes and in human epithelial and endothelial cell lines after dengue virus challenge. J Virol 2002;76(11):5588-5597.

9. Suharti C, van Gorp EC, Dolmans WM, Setiati TE, Hack CE, Djokomoeljanto R, et al. Cytokine patterns during dengue shock syndrome. Eur Cytokine Netw 2003;14(3):172-177.

10. Libraty DH, Pichyangkul S, Ajariyakhajorn C, Endy TP, Ennis FA. Human dendritic cells are activated by dengue virus infection: enhancement by gamma interferon and implications for disease pathogenesis. J Virol 2001;75(8):3501-3508.

11. Chen LC, Lei HY, Liu CC, Shiesh SC, Chen SH, Liu HS, et al. Correlation of serum levels of macrophage migration inhibitory factor with disease severity and clinical outcome in dengue patients. Am J Trop Med Hyg 2006;74(1):142147.

12. Stephens HA, Klaythong $R$, Sirikong $M$, Vaughn DW, Green S, Kalayanarooj S, et al. HLA-A and -B allele associations with secondary dengue virus infections correlate with disease severity and the infecting viral serotype in ethnic Thais. Tissue Antigens 2002; 60(4):309318.

13. Juffrie $M$, van Der Meer GM, Hack CE, Haasnoot K, Sutaryo, Veerman AJ, et al.
Inflammatory mediators in dengue virus infection in children: interleukin-8 and its relationship to neutrophil degranulation. Infect Immun 2000;68(2):702-707.

14. Promphan W, Sopontammarak S, Pruekprasert P, Kajornwattanakul W, Kongpattanayothin A. Dengue myocarditis. Southeast Asian J Trop Med Public Health 2004;35(3):611-613.

15. Salgado D, Panqueba C, Vega R, Garzón M, Castro D, Rodríguez, J. Mortalidad por dengue hemorrágico en niños en Colombia: más allá del choque. Infectio 2008;12(1):247-253.

16. Salgado DM, Panqueba CA, Castro D, M RV, Rodriguez JA. [Myocarditis in children affected by dengue hemorrhagic fever in a teaching hospital in Colombia]. Rev Salud Pública (Bogotáa). 2009;11(4):591-600.

17. Salgado DM, Eltit JM, Mansfield K, Panqueba C, Castro D, Vega MR, et al. Heart and Skeletal Muscle Are Targets of Dengue Virus Infection. Pediatr Infect Dis J 2010 Dec 21.

18. Green S, Rothman A. Immunopathological mechanisms in dengue and dengue hemorrhagic fever. Curr Opin Infect Dis 2006;19(5):429436.

19. Avirutnan P, Malasit P, Seliger B, Bhakdi S, Husmann M. Dengue virus infection of human endothelial cells leads to chemokine production, complement activation, and apoptosis. $J$ Immunol 1998 Dec. 1;161(11):6338-6646.

20. Warke RV, Xhaja K, Martin KJ, Fournier MF, Shaw SK, Brizuela N, et al. Dengue virus induces novel changes in gene expression of human umbilical vein endothelial cells. J Virol 2003;77(21):11822-11832.

21. Kurane I. Dengue hemorrhagic fever with special emphasis on immunopathogenesis. Comp Immunol Microbiol Infect Dis 2007;30(56):329-340.

22. Marianneau P, Steffan AM, Royer C, Drouet MT, Jaeck D, Kirn A, et al. Infection of primary cultures of human Kupffer cells by Dengue virus: no viral progeny synthesis, but cytokine production is evident. J Virol 1999;73(6):52015206.

23. King CA, Anderson R, Marshall JS. Dengue virus selectively induces human mast cell chemokine production. J Virol 2002;76(16):84088419 .

24. King CA, Marshall JS, Alshurafa H, Anderson $R$. Release of vasoactive cytokines by antibodyenhanced dengue virus infection of a human 
mast cell/basophil line. J Virol 2000;74(15):71467150 .

25. Nguyen TH, Lei HY, Nguyen TL, Lin YS, Huang KJ, Le BL, et al. Dengue hemorrhagic fever in infants: a study of clinical and cytokine profiles. J Infect Dis 2004;189(2):221-232.

26. Chaturvedi UC. Shift to Th2 cytokine response in dengue haemorrhagic fever. Indian J Med Res 2009;129(1):1-3.

27. Chaturvedi UC, Elbishbishi EA, Agarwal R, Raghupathy R, Nagar R, Tandon R, et al. Sequential production of cytokines by dengue virus-infected human peripheral blood leukocyte cultures. J Med Virol 1999;59(3):335340.

28. Kurane I, Innis BL, Nimmannitya S, Nisalak A, Meager A, Janus J, et al. Activation of T lymphocytes in dengue virus infections. High levels of soluble interleukin 2 receptor, soluble CD4, soluble CD8, interleukin 2, and interferongamma in sera of children with dengue. J Clin Invest 1991;88(5):1473-1480.

29. Azeredo EL, Zagne SM, Santiago MA, Gouvea AS, Santana AA, Neves-Souza PC, et al. Characterisation of lymphocyte response and cytokine patterns in patients with dengue fever. Immunobiology 2001;204(4):494-507.

30. Kubelka CF, Borges PA, VonSydow FF, Lampe E. Analysis of tumor necrosis factoralpha serum level in Brazilian patients with
Dengue-2. Mem Inst Oswaldo Cruz 1995;90(6):741-742.

31. Atrasheuskaya A, Petzelbauer P, Fredeking TM, Ignatyev G. Anti-TNF antibody treatment reduces mortality in experimental dengue virus infection. FEMS Immunol Med Microbiol 2003;35(1):33-42.

32. Huang YH, Lei HY, Liu HS, Lin YS, Liu CC, Yeh TM. Dengue virus infects human endothelial cells and induces IL-6 and IL-8 production. Am J Trop Med Hyg 2000;63(1-2):71-75.

33. Bozza FA, Cruz OG, Zagne SM, Azeredo EL, Nogueira RM, Assis EF, et al. Multiplex cytokine profile from dengue patients: MIP1 beta and IFN-gamma as predictive factors for severity. BMC Infect Dis 2008;8:86.

34. Srikiatkhachorn A, Green S. Markers of Dengue Disease Severity. Current Topics in Microbiology and Immunology 2009;1(2):68-79.

35. Zivna I, Green S, Vaughn DW, Kalayanarooj S, Stephens HA, Chandanayingyong D, et al. T cell responses to an $\mathrm{HLA}^{-\mathrm{B}^{*} 07-\text { restricted }}$ epitope on the dengue NS3 protein correlate with disease severity. J Immunol 2002;168(11):5959-5965.

36. Restrepo BN, Ramírez R, Arboleda M, Álvarez G, Ospina M, Díaz FJ. Levels of cytokines in two ethnic groups with dengue virus infection. Am J Trop Med Hyg 2008;79(5):673-677. 


\section{POSGRADOS CLÍNICOS}

Universidad

Surcolombiana

\section{ESPECIALIZACIÓN EN PEDIATRÍA}

Registro ICFES No. 111456180924100111400

Creada mediante acuerdo Consejo Superior Universitario No. 034 del 29-05-1996

Denominación Académica: Programa de Especialización en Pediatría

Modalidad:

Presencial

Duración:

3 años (6 semestres)

Cupos:

3 Anual

Título:

Especialista en Pediatría

\section{ESPECIALIZACIÓN EN CIRUGÍA GENERAL}

Registro ICFES No. 111456170004100111400

Creada mediante acuerdo Consejo Superior Universitario No. 035 del 29-05-1996
Denominación Académica:
Programa de Especialización en Cirugía General
Modalidad:
Teórico - Presencial
Duración:
4 años (8 semestres)
Cupos:
2 Anuales
Título:
Especialista en Cirugía General

\section{ESPECIALIZACIÓN EN GERENCIA DE SERVICIOS DE SALUD Y SEGURIDAD SOCIAL}

Creada mediante acuerdo Consejo Superior Universitario No. 021 del 10-07-1995

SNIES No. 3503, Registro calificado de calidad Res. No 450 de febrero 5 de 2008

Ministerio de Educación Nacional.

Denominación Académica: Programa de Especialización en Gerencia de Servicios de salud y Seguridad Social

Modalidad:

Semipresencial

Duración:

3 semestres

Cupos:

25 Anuales

Título:

Especialista en Gerencia de Servicios de salud y Seguridad Social 